\title{
A new salterellid (Phylum Agmata) from the upper Middle Cambrian of Denmark
}

\author{
JOHN S. PEEL AND VIVIANNE BERG-MADSEN
}

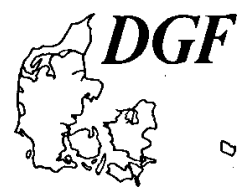

Peel, J. S. \& Berg-Madsen, V.: A new salterellid (Phylum Agmata) from the upper Middle Cambrian of Denmark. Bull. geol. Soc. Denmark, Vol. 37, pp. 75-82, Copenhagen, October 14th, 1988. https://doi.org/10.37570/bgsd-1988-37-07

A new salterellid genus and species, Ellisell yochelsoni, is described from the upper Middle Cambrian Andrarum Limestone of Bornholm, Denmark. The genus is an undoubted Middle Cambrian record of a phylum otherwise widely considered to be characteristic of the Early Cambrian.

John S. Peel, Geological Survey of Greenland, Øster Voldgade 10, DK-1350 Copenhagen K, Denmark. Vivianne Berg-Madsen, Geological Institute, Stockholm University, Box 6801, Stockholm S-10691, Sweden, April 20 th 1988.

Small $(c .1 \mathrm{~cm})$ Early Cambrian conical fossils which Yochelson (1977) placed within his new Phylum Agmata had previously been interpreted as cephalopods, worms, foraminifers or even the isolated radular teeth of a mollusc (see Yochelson, 1977 for discussion and references). The best known members are the genera Salterella Billings, 1861 , which is characteristic of the Cambrian of North America, and Volborthella Schmidt, 1888 , which is principally reported from the Lower Cambrian of Europe (Yochelson, 1977, 1981; Fritz \& Yochelson, in press). Campitius Firby \& Durham, 1974 from the Lower Cambrian of California and Nevada is a third representative of the phylum. Opinions differ as to the significance of the three taxa. Yochelson (1977, 1983; in Fritz \& Yochelson, in press) recognises only a single genus, Salterella; other authors consider all three taxa to be useful (Fritz in Fritz \& Yochelson, in press; Signor et al., 1985) and even distribute the three genera between two families, Salterellidae and Volborthellidae (Signor et al., 1985).

All the cited authors agree that agmatans are characterised by a cone of laminated deposits around a central tube but they disagree about the extent to which the laminated deposits were enclosed within a calcareous outer wall (Fig. 1). All agree that such a thin-walled sheath is present in Salterella and absent in Volborthella and Campitius. The disagreement centres upon whether the absence of the outer wall in Volborthella and Campitius is an original feature or the result of diagenesis.

Following examination of a wide range of material of the two principal taxa, Yochelson (1977, 1983; see also Yochelson et al., 1977) concluded that the absence of the outer calcareous sheath in Volborthella was a diagenetic feature resulting from chemical solution in reducing environments or simple abrasion. Thus, Volborthella is merely a preservational variant of Salterella in the opinion of Yochelson and should be placed in its synonymy. In a published abstract, Signor et. al. (1985) considered that an outer sheath was not developed in Campitius (nor, by implication, in Volborthella) and that delimitation of taxa on the presence or absence of this feature was thus a valid procedure.

There can be little doubt that Yochelson has demonstrated that diagenesis can produce $\mathrm{Vol}$ borthella-like specimens from Salterella (Yochelson, 1983) but this does not mean that all "Volborthella" formed in this way. On the other hand, it is difficult to escape the necessity in Volborthella and Campitius for some kind of sheath to act as containment for the inner laminated deposits. In particular, the deep apertural cavity of Salterella has no equivalent in the other two genera. Perhaps a non-mineralised sheath was present in Campitius and Volborthella in which case proponents of a sequence of the three genera 


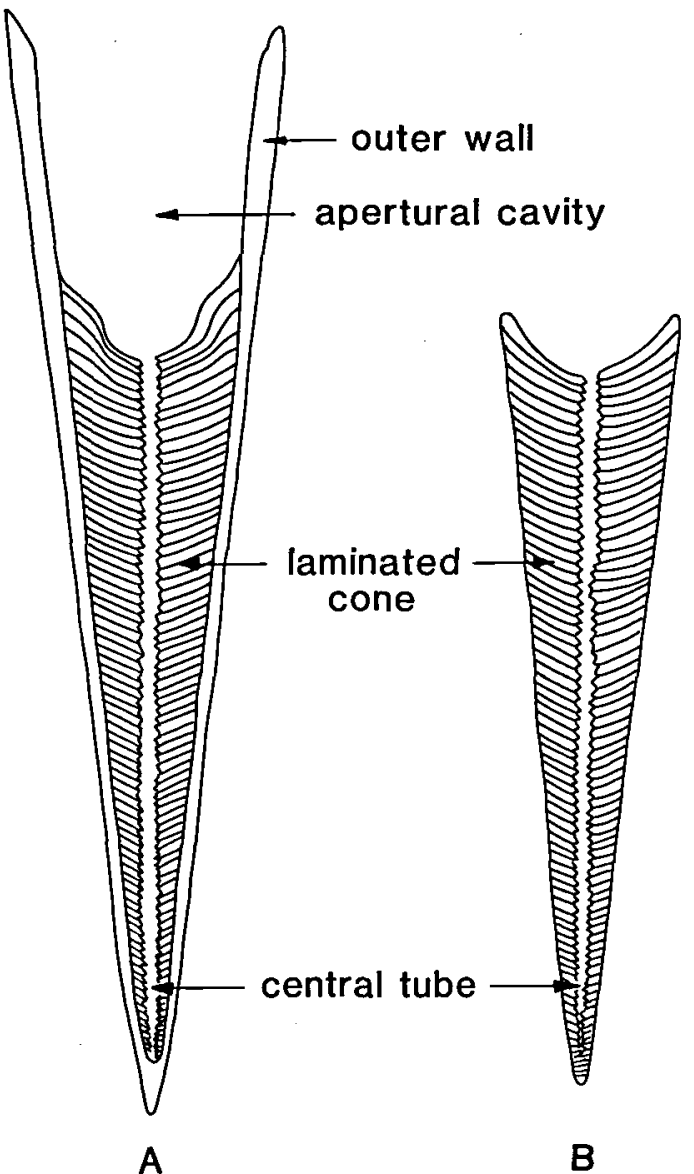

Fig. 1. Principal morphological features of the Phylum Agmata. A, Salterella, in which the cone of laminated deposits is contained within a calcareous outer wall which delimits an apertural cavity. B, Volborthella, in which the laminated cone is not contained within an outer sheath; the term apertural cavity has little applicability. Volborthella is shown with a pointed apex, in similar fashion to Salterella, but the apex is commonly not preserved (modified after Fritz \& Yochelson, in press).

from the earliest to late Early Cambrian can invoke calcification as an evolutionary trend within the phylum.

This paper greatly extends the geological range of agmatans by describing a new genus and species, Ellisell yochelsoni, from strata of late Middle Cambrian age from Bornholm, Denmark (Fig. 2). The specimens in question were collected from the Andrarum Limestone exposed in the banks of the brook Ølea at Borregård. The Andrarum Limestone contains trilobites indicative of the Solenopleura brachymetopa Zone (Paradoxides forchhammeri zonal group) of the late Middle Cambrian (Berg-Madsen, 1985).

\section{Preservation and methods of study}

Most modern studies of agmatans are based on longitudinal thin sections of the conch (Figs 1, 3). In Salterella such sections may show clearly the essential features of the thin outer wall, the apertural cavity and central tube, and the inner cone of laminated deposits (Fig. 3F). In Volborthella, the laminated deposits and central tube are present (e.g. Yochelson et al., 1977, figs. 1-4; Rozanov, 1983, pl. 89, figs 3,4) but an outer wall is absent; the term apertural cavity has little applicability in Volborthella since the abapical area presumably occupied by the body mass lacks lateral or apertural definition in preserved material. Recrystallisation of the entire conch may obscure the recognition of lamination and the delimitation of the outer wall from the laminated deposits in Salterella (e.g. Peel \& Yochelson, 1982, fig. 5).

Agmatans are also described on the basis of three-dimensionally preserved material (e.g. Firby \& Durham, 1974; Rozanov, 1983, pl. 90; Yochelson, 1977; Fritz \& Yochelson, in press). Such specimens of Salterella sometimes show growth ornamentation transverse to the length of the conch or, as a result of weathering, transverse rugae reflecting the eroded edges of the internal laminated deposits.

Internal moulds of Salterella have not been used previously as a basis for description. The illustrated specimens from the Lower Cambrian Forteau Formation of western Newfoundland (Figs 4H-M) clearly show the form of both the conical apertural cavity and the central tube. That such specimens are correctly assigned to Salteralla is evident from comparison with the dark, sediment-filled apertural cavity and central tube in the specimen illustrated as Fig. 3B. The internal mould of the central tube in the specimens from Newfoundland tapers adapically and is frequently crudely annulated. The annulation is produced by the succession of inner laminations (cf. Fig. 3D). The mould of the central tube often tapers to a fine point (Figs $4 \mathrm{H}, \mathrm{I}$ ).

The few specimens of Ellisell yochelsoni, described below, known in thin section are recrystallised and the diagnostic agmatan inner lamination is not visible (Fig. 3C). However, comparison of internal moulds of Salterella with those of Ellisell leaves no doubt that a laminated inner cone was present within the latter genus. Speci- 


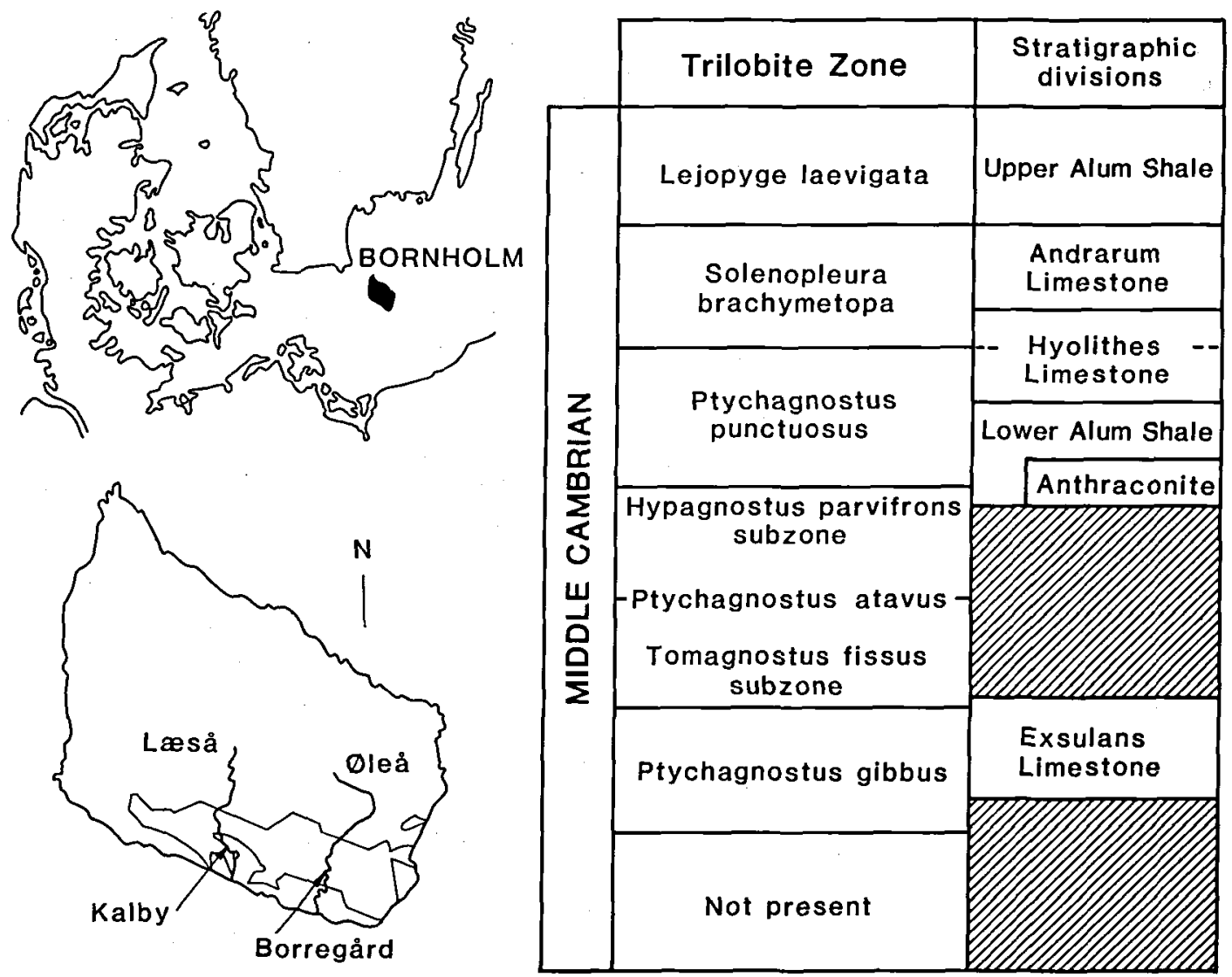

Fig. 2. Details of collection locality and stratigraphy for Ellisell yochelsoni on Bornholm, Denmark. Figured specimens were collected from the Andrarum Limestone along the stream Øleå in southern Bornholm.

mens of $E$. yochelsoni show the same annulation of the mould of the central tube as is seen in Salterella (Fig. 4). The mould of the apertural cavity in the former species is more cylindrical in form than that in Salterella, but both show low amplitude transverse undulations (cf. Figs $4 \mathrm{C}$, H).

\section{Stratigraphic record of agmatans}

The stratigraphic distribution of agmatans has been summarised in some detail by Yochelson $(1977,1981)$ and Fritz \& Yochelson (in press) who noted that the phylum was restricted to the Early Cambrian. Prantl (1948) described Volborthella from the Middle Cambrian of Czechoslovakia (see also Rozanov, 1983) but Yochelson
(1977, p. 441) comments that the specimens cannot be found and that detailed search has not produced additional material.

Disagreement concerning the status of Volborthella and Campitius relative to Salterella is also reflected in opinions concerning stratigraphic distribution. Yochelson maintains that Salterella (in his view the only agmatan) is characteristic of the late Early Cambrian and that older ages assigned to strata yielding Volborthella (which he considers a junior synonym of Salterella) are in error. Fritz (see also Rozanov, 1983) favours an older Volborthella, following the views of various mainly European workers, with Salterella s. s. indicating a late Early Cambrian age (Bonnia Olenellus Zone). Fritz also supports the interpretation of Campitius as a volborthellid agmatan (early Early Cambrian, pre-trilobite zone-Nevadella Zone), as suggested by Signor et al. (1985). 

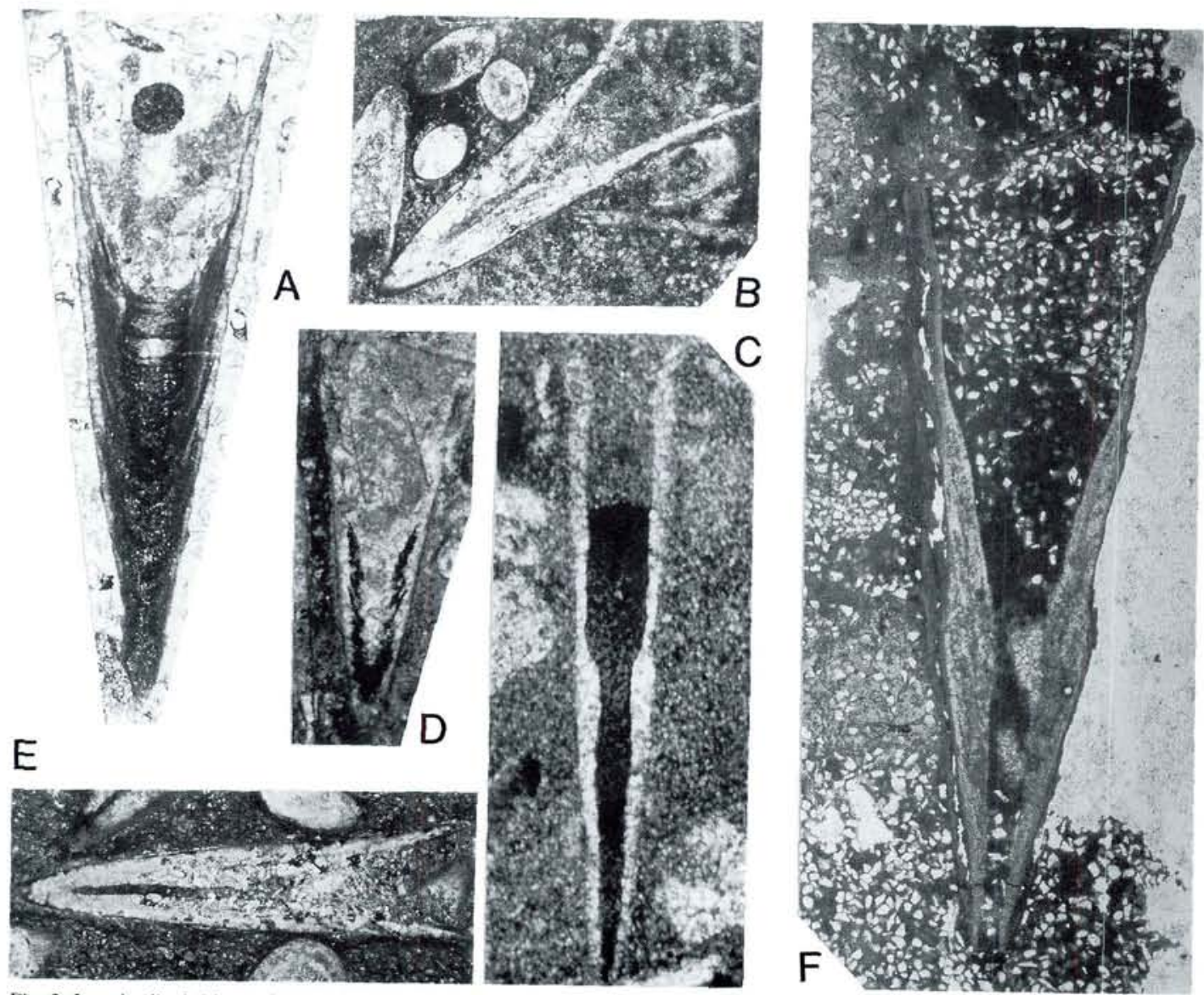

Fig. 3. Longitudinal thin sections of Cambrian agmatans. A, B, D-F, Salterella maccullochi (Murchison), all specimens are of Early Cambrian age. A, MGUH 15.913, Hyolithus Creek Formation, Kap Weber, East Greenland, × 10. B, D, from USNM 115677a, b, a slab containing the holotype and one figured paratype of $S$. mexicana Lochman (a junior subjective synonym of $S$. maccullochi), Buelna Formation, Caborca, Sonora, Mexico, $\times 10$. E, from USNM $115674 \mathrm{a}-\mathrm{c}$, a slab containing figured paratypes of $S$. mexicana Lochman, Buelna Formation, Caborca, Sonora, Mexico, $\times 10$. F, MGUH 15.087, Wulff River Formation, Inglefield Land, North-West Greenland, $\times$ 15. C, Ellisell yochelsoni gen. et sp. nov., MGUH 18.644, holotype, Andrarum Limestone, late Middle Cambrian, Bornholm, Denmark, $\times 50$.

The description of Ellisell yochelsoni from the Andrarum Limestone of Bornholm extends the range of the Phylum Agmata almost to the end of the Middle Cambrian. It has no direct influence on the stratigraphic controversy surrounding other members of the phylum since E. yochelsoni is readily distinguished from all of the three genera in question. Neither does the description of

Fig. 4. Scanning electron micrographs of phosphatised internal moulds of Cambrian agmatans, See Fig. 1 for interpretation. A-G, Ellisell yochelsoni gen. et sp. nov., Andrarum Limestone, late Middle Cambrian, Bornholm, Denmark. Note the essentially cylindrical mould of the apertural cavity and the rod-like mould of the central tube. A-C, MGUH 18.645; A, detail of internal mould of the central tube showing annulation produced by the inner margins of successive inner laminations and the fibrous texture of phosphate replacing aragonite, $\times 440 ; \mathrm{B}, \mathrm{C}$, oblique views, $\times 60$. D, G, MGUH 18.646 ; D, lateral view, $\times 60 ; \mathrm{G}$, lateral view showing coarsely annulated internal mould of the central tube, $\times 100$. E, MGUH 18.647 , lateral view, $\times 60$. F, MGUH 18.648 , lateral view, $\times 60$.

H-M, Salterella ef. S. maccullochi, Forteau Formation (late Early Cambrian), road cut $12 \mathrm{~km}$ east of Rocky Harbour on Highway 73 , near the head of Dear Arm, Gros Morne, western Newfoundland (James \& Stevens 1982, pp. 68-69, stop 23). Note the conical form of the mould of the apertural cavity and the rod-like internal mould of the central tube; mineral matter adheres to the internal mould in Figs 1, K, L. H, MGUH 18.649, × 40. I, MGUH 18.650, × 40. J, MGUH 18.651, × 20. K. MGUH 18.652, $\times 20$. L, MGUH $18.653, \times 30 . \mathrm{M}, \mathrm{MGUH} 18.654$, internal mould of central tube showing annulation produced by laminated deposits, $\times 20$. 


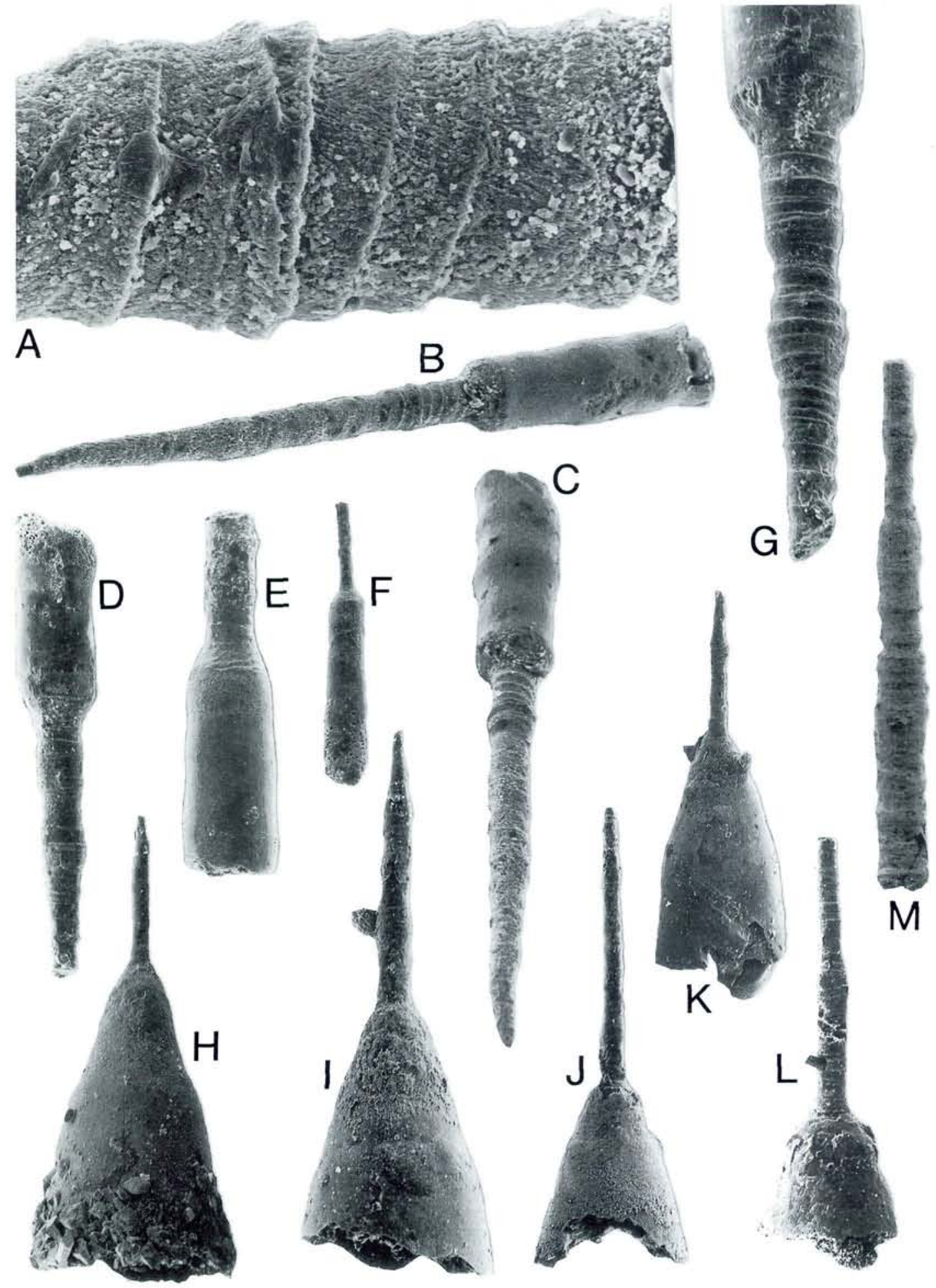


Ellisell detract directly from the known stratigraphic value of Salterella s. $s$. as an index fossil to the late Early Cambrian in North America. However, in view of the current lack of undisputed records of agmatans from older Middle Cambrian strata, some degree of caution is obviously necessary in automatically assuming an Early Cambrian age on the basis of occurrence of Salterella alone.

\section{Systematic Palaeontology}

Phylum Agmata Yochelson, 1977

Family Salterellidae Walcott, 1886

Genus Ellisell gen. nov.

Type species. - Ellisell yochelsoni gen. et sp. nov.

Derivation of name. - For Ellis L. Yochelson in celebration of his 60th year, in appreciation of his contribution to the understanding of the Agmata and the Palaeozoic history of molluscs.

Diagnosis. - A salterellid agmatan in which the slowly expanding conch contains a cylindrical apertural cavity about half the length of the conch. The central tube is clearly demarcated from the apertural cavity and is usually more than half its width. The wall of the conch is apparently thick relative to the narrow, inner cone of laminated deposits. Shell structure and ornamentation are not known, although the internal laminated deposits may have been aragonite.

Discussion. - Interpretation of Ellisell yochelsoni as an agmatan depends primarily on recognition of the inner cone of laminated deposits. These deposits can not be discerned in thin-section (Fig. 3C) due to recrystallisation, a diagenetic process also familiar in Salterella (cf. Fig. 3D). However, the presence of annulations around the internal mould of the central tube is solid evidence that such lamination existed in E. yochelsoni (Figs 4A-G), by direct comparison with similar structures preserved on the internal moulds of Salterella (Figs $4 \mathrm{H}-\mathrm{M})$. Neither can it reasonably be argued that these latter mentioned internal moulds from the Forteau Formation of Newfoundland are not Salterella, as seen by comparing
Figs $4 \mathrm{H}-\mathrm{L}$ with the dark filling of the central tube and apertural cavity in the specimens of Salterella maccullochi described by Peel \& Yochelson (1982) and figured here as Figs 3B, F.

A suggestion that Ellisell yochelsoni may be a volborthellid, with the recrystallised conch composed entirely of laminated deposits without any containing outer wall is also rejected. Volborthella and Campitius possess only the shallowest of apertural cavities, a mere depression within the upper surface of the final preserved lamination (cf. Fig. 1B; see also Yochelson et al., 1977, fig. 2). In E. yochelsoni the apertural cavity accounts for almost half the length of the conch. In addition, the abrupt transition between the internal mould of the apertural cavity and the narrow adaxially sloping surface which connects this part of the internal mould with that of the internal mould of the central tube in $E$. yochelsoni (Fig. 4G) suggests that the narrow laminae abutted against the inside of the outer wall at this point. This interpretation is strengthened by the existence of sharp seams precisely at the shoulder of the mould of the apertural cavity (Figs 4D, G) and immediately adapertural of the shoulder. These seams mark the junction between laminations and the inner surface of the conch wall. No trace of any other form of annulation comparable to those seen on the mould of the central tube has been observed on moulds of the apertural cavity.

Ellisell is clearly distinguished from Salterella by its more slowly expanding conch and the resulting cylindrical apertural cavity. In Salterella the conch expands more rapidly and the apertural cavity is typically cone-shaped. The difference is most clearly seen by comparing internal moulds (compare Figs $4 \mathrm{~B}-\mathrm{G}$ with Figs $4 \mathrm{H}-\mathrm{L}$ ). In addition, the central tube in Ellisell tends to be both relatively thicker and more abruptly delimited from the apertural cavity.

Ellisell is readily distinguished from both $\mathrm{Vol}$ borthella and Campitius by the lack in these genera of a mineralised conch wall. The latter named genera also have wider, more rapidly expanding conchs than Ellisell, and relatively narrower central tubes. Comparison of the form of the apertural cavity is not possible since this feature is not preserved in any described material of either Campitius or Volborthella.

Ellisell differs from Lidaconus Onken \& Signor, 1988 from the Lower Cambrian of Nevada 
in both the form of the conch and the absence of inner laminated deposits in the latter genus. In Lidaconus, which occurs together with Salterella but is not an agmatan (Onken \& Signor, 1988), the conch is curved and more rapidly expanding than in Ellisell.

The outer surface of the conch in Ellisell is not known. In Salterella the conch is commonly ornamented by closely spaced, slightly wavy growth lines (Fritz \& Yochelson, in press).

Ellisell yochelsoni gen. et sp. nov.

Figures 3D, 4A-G

Holotype. - MGUH 18.644, from the Andrarum Limestone, Middle Cambrian, Borregård, Bornholm, Denmark.

Figured paratypes. - MGUH 18.645-18.654, from the same locality and horizon as the holotype.

Additional material. - A few random thin-sections and about 20 internal moulds from the same locality and horizon.

Description. - Type species of Ellisell in which the slender conch with very slightly convex sides expands with an apical angle of about 9 degrees. The apertural cavity occupies about half of the length of the conch in the holotype (the only specimen in which the aperture is preserved); its shape is overall cylindrical but slight variation in width produces a shallowly billowing profile (Figs $4 B, C)$. The apertural cavity narrows abruptly with passage adapically into the central tube, the diameter of which is usually more than half the diameter of the apertural cavity itself. The central tube tapers somewhat irregularly towards its apical termination. The conch wall is apparently thin at its apex but there is no evidence to suggest that the conch is perforated. The walls of the central tube are annulated in an irregular, steplike form, reflecting the layered structure of the inner, laminated, cone. The laminated cone appears to be narrow, relative to the thickness of the shell in the apertural region (Fig. 3C) but details of this relationship are effectively obscured by recrystallisation. The external ornamentation of the conch is not known.
Discussion. - Ellisell yochelsoni is currently the only known species assigned to the genus Ellisell. Specimens from the Andrarum Limestone here assigned to $E$. yochelsoni were illustrated but not identified by Berg-Madsen (1985, figs 5E, F).

Preserved shell structure. - Runnegar (1985) has described numerous examples of replication of the shell microstructure by phosphate forming internal moulds of Cambrian molluscs. In particular, he noted fibrous structures on internal moulds of the paragastropod Pelagiella which he considered to be replicas of fibrous aragonite. Close inspection of the surface of a phosphatised internal mould of the central tube of one specimen of E. yochelsoni (Fig. 4A) has revealed a similar fibrous structure with orientation of the fibres essentially perpendicular to the step-like annulations representing the edges of the successive layers of the internal laminated cone. No replication of shell structure has been observed on the internal mould of the body cavity but it would appear that the internal laminated deposits of $E$. yochelsoni may have been formed principally of aragonite.

Individual laminations of salterellid agmatans consist of grains of sediment cemented by calcium carbonate (Yochelson, 1977); these laminations may be separated by layers of calcium carbonate. In Volborthella carbonate is much less significant (e.g. Yochelson et al., 1977) or totally absent (Rozanov, 1983) and the laminations are thus composed almost entirely of silt-size particles.

Acknowledgments. Bill Fritz, Phil Signor and Ellis Yochelson are thanked for constructive comments concerning the first draught of the manuscript. We are unable to reconcile their several points of view but have attempted to answer their criticisms in the course of our description.

MGUH and USNM denote the type collections of the Geological Museum, Copenhagen, and National Museum of Natural History, Washington D.C., respectively. SEM photographs were taken in the Laboratory for Electron Microscopy, University of Copenhagen. Peel publishes with permission from the Director, Geological Survey of Greenland.

\section{Dansk Sammendrag}

Ellisell yochelsoni gen. et sp. nov. er beskrevet på basis af materiale fra Andrarumkalk (Mellem Kambrium) på Bornholm. Slægten sammenlignes med de øvrige medlemmer af Phylum Agmata, d.v.s. Salterella, Volborthella og Campitius. Ellisell er den yngste slagt $i$ en gruppe med karakteristisk Nedre Kambrium distribution i Nordamerika og Europa. 


\section{References}

Berg-Madsen, V. 1985: A review of the Andrarum Limestone and the upper alum shale (Middle Cambrian) of Bornholm, Denmark. Bull. geol. Soc. Denmark 34, 133-143.

Firby, J. B. \& Durham, J. W. 1974:-Molluscan radula from earliest Cambrian. Jour. Paleont. 43, 1109-1119.

Fritz, W. H. \& Yochelson, E. L. in press. The status of Salterella as a Lower Cambrian index fossil. Can. J. Earth Sci. 25.

James, N. P. \& Stevens, R. K. 1982: Excursion 2B: anatomy and evolution of a Lower Paleozoic continental margin, western Newfoundland. Ilth Internatl. Congr. Sedimentol_ogy, McMaster Univ. Internatl. Assoc. Sedimentol. field excursion book, $75 \mathrm{pp}$.

Onken, B. R. \& Signor, P. W. 1988: Lidaconus palmettoensis n. gen. and sp.: an enigmatic Early Cambrian fossil from Western Nevada. J. Paleont. 62, 172-180.

Peel, J. S. \& Yochelson, E. L. 1982: A review of Salterella (Phylum Agmata) from the Lower Cambrian in Greenland and Mexico. Rapp. Grønlands Geol. Unders. 108, 31-39.

Prantl, F. 1948: On the occurrence of the genus Volborthella Schmidt in Bohemia (Nautiloidea). Sb. narod. Mus. $v$ Praze 4B, 5, 3-13.

Rozanov, A. Yu. 1983: Volborthella. In Urbanek, A. \& Roza- nov, A. Yu. (edit.) Upper Precambrian and Cambrian Palaeontology of the East-European Platform, 111-113. Warszawa: Wydawnictwa Geodogiczne.

Runnegar, B. 1985: Shell microstructures of Cambrian molluscs replicated by phosphate. Alcheringa 9, 245-257.

Signor, P. W., Lipps, J. H., Durham, J. W. \& Firby-Durham, J. B. 1985: The volborthellid Campitius and the relationship of the Volborthellidae and Salterellidae (Phylum Agmata). Geol. Soc. Am. Abstr. with programs 17, 7, 717 (only).

Yochelson, E. L. 1970: The Early Cambrian Fossil Salterella conulata Clark in Eastern North America. [U.S.] Geol. Survey Prof. Pap. 683-B, B1-B10.

Yochelson, E. L. 1977: Agmata, a proposed extinct phylum of Early Cambrian age. Jour. Paleont. 51, 437-454.

Yochelson, E. L. 1981: A survey of Salterella (Phylum Agmata). U.S. Geol. Survey Open-file Report 81-743, 244-248.

Yochelson, E. L. 1983: Salterella (Early Cambrian; Agmata) from the Scotish Highlands. Palaeontology 26, 253-260.

Yochelson, E. L., Henningsmoen, G. \& Griffin, W. L. 1977: The Early Cambrian genus Volborthella in southern Norway. Norsk geol. Tidsskr. 57, 133-151.

Yochelson, E. L. \& Peel, J. S. 1980: Early Cambrian Salterella from north-west Greenland. Grønlands Geol. Unders. Rap. 101, 29-36. 